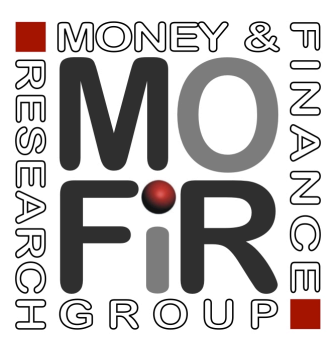

\title{
THE IMPACT OF NATURAL DISASTERS ON REMITTANCES TO LOW- AND MIDDLE-INCOME COUNTRIES
}

\author{
Giulia Bettin Alberto Zazzaro
}

Working paper no. 120

February 2016 


\title{
The impact of natural disasters on remittances to low- and middle-income countries*
}

\author{
Giulia Bettin $^{\dagger} \quad$ Alberto Zazzaro ${ }^{\ddagger}$
}

February 18, 2016

\begin{abstract}
In this paper, we offer novel empirical evidence on the impact of natural disasters on remittance flows towards low- and middle-income countries. We consider a panel of 98 countries over the period 1990-2010. Our findings show that remittances increase after a disaster, thus contributing ex post to the reconstruction process. At the same time, we find that remittances play a key role in terms of ex ante risk preparedness for those countries that experienced more disruptive events in the past. Finally, when taking into account the interaction with the level of development of the local financial sector, remittances seem to substitute for less efficient financial systems both in terms of ex post response to disasters and in terms of ex ante risk management strategy.
\end{abstract}

JEL codes: migrants' remittances, international migration, natural disasters

Keywords: F24, F22, Q54

${ }^{*}$ We would like to thank participants at the First Annual Conference of the Italian Association of Environmental and Resource Economists (Ferrara) and the CSAE Conference (Oxford) for useful comments and suggestions on a preliminary version of this paper.

${ }^{\dagger}$ Dipartimento di Scienze Economiche e Sociali \& Mo.Fi.R.- Università Politecnica delle Marche - P.le Martelli 8, 60121 Ancona (Italy) - Email address: g. bettin@univpm.it.

‡Università di Napoli Federico II, Università Politecnica delle Marche, MoFiR \& CSEF. Email address: alberto.zazzaro@unina.it \& a.zazzaro@univpm.it. 


\section{Introduction}

The frequency of natural disasters has markedly increased in the last few decades (Cavallo and Noy, 2009). Between 1975 and 2011 the number of disasters rose from less than 100 to almost 350 events per year, with peaks of more than 500 disasters at the beginning of the $2000 s^{1}$. In particular, weather-related natural disasters - hydrological, meteorological and climatological - have become extremely frequent, both in rich and in poor countries, due to changing climatic conditions and widespread environmental degradation (Parry, Canziani, Palutikof, van der Linden, and Hanson, 2007). As a result, increasing resilience of developing countries to climate changes and natural disasters has risen up the agenda of many governments and development agencies (World Bank, 2013).

The economic literature has mainly focussed on the influence such catastrophic events have on economic growth, without providing conclusive evidence; several studies document a significant negative impact on growth (Rasmussen, 2004; Raddatz, 2007; Noy, 2009; Strobl, 2012), while others find no significant adverse effects (Albala-Bertrand, 1993) or even positive effects (Skidmore and Toya, 2002; Loayza, Olaberría, Rigolini, and Christiaensen, 2012). According to Kahn (2005), rich countries seem to suffer less from disasters, both in terms of death toll and economic damage, as they can build effective (and costly) defenses against natural adverse events and maintain resilience to them. ${ }^{2}$ Indeed, the Intergovernmental Panel on Climate Change (2001) reports that $65 \%$ of world deaths from natural disasters between 1985 and 1999 took place in nations whose per capita incomes were below $\$ 760$ per annum.

The policy debate highlights the multiple strategies that public authorities in developing countries should put in place to build a climate-resilient development process in terms of risk prevention, risk protection and emergency management (Keen, Freeman, and Mani, 2003; Laframboise and Loko, 2012; Adam, 2013; World Bank, 2013). However, it is just as important to investigate household strategies to mitigate and cope with the destruction of physical and human capital stocks caused by natural disasters. In this perspective, migration and related remittance flows represent mechanisms that households might exploit ex ante as informal insurance and/or ex post as handling strategies in the presence of disruptive weather-related shocks (Skoufias, 2003).

A number of recent studies have analyzed the effect of natural disasters in shaping international migration, showing that a rise in the number of people affected by weatherrelated disasters significantly acts as a push factor in increasing out-migration flows towards rich countries (Reuveny and Moore, 2009; Drabo and Mbaye, 2011). This effect is particularly strong in communities with a long emigration tradition, where diaspora networks are more widespread (Hunter, Murray, and Riosmena, 2013). While outmigra-

\footnotetext{
${ }^{1}$ See http:/ / www.emdat.be/natural-disasters-trends.

2 Various aspects such as education, openness, institutional quality and financial development (Rasmussen, 2004; Kahn, 2005; Toya and Skidmore, 2007; Noy, 2009) all seem to be effective at reducing the disruptive impact of natural disasters.
} 
tion could exacerbate the risk of brain drain and the loss of human resources which are essential to recovery, poor countries might also receive larger remittance flows from their diaspora abroad in response to natural disasters (Le De, Gaillard, and Friesen, 2013). Altruistic migrants in fact are likely to increase their transfers to relatives, friends and communities in the country of origin to support them within the reconstruction process. In addition, migrants from countries repeatedly affected by natural catastrophes might take into account the higher risk of asset destruction and income volatility their relatives back home have to face and hence send larger amounts of money as an ex ante risk management strategy (Ebeke and Combes, 2013). Remittances might help diversify income sources, moving productive activities to less affected areas or adopting technologies more resistant to natural harshness (Mohapatra, Joseph, and Ratha, 2012). This ex ante informal insurance mechanism might derive either from altruism or from ad hoc contracts between migrants and household members who stayed at home.

At the micro level, anecdotal evidence on the positive response of remittances to disasters has been provided by analyzing case studies mainly related to Central America or South Asia. ${ }^{3}$ However, the link between natural disasters and remittance flows to low- and middle-income countries is still relatively unexplored in the literature at the aggregate level. ${ }^{4}$ Yang (2008) looks at the impact of a specific type of natural disasterhurricanes -on international financial flows to developing countries across Africa, Asia and Latin America. Unlike foreign aid, which reacts positively to hurricane exposure everywhere, remittances received from migrants abroad increase only in the very poor home countries. In a similar vein, David (2011) analyzes the behavior of international financial flows in response to climatic and geological disasters in 78 developing countries for the period 1970-2005, but reaching opposite results: remittance flows positively respond to disasters while international aid seems to play a limited role in attenuating the negative consequences of such events. Mohapatra, Joseph, and Ratha (2012) also provide evidence of a positive response of remittances following natural disasters (meteorological, climatological, geophysical) in a study which included 129 countries for the period 1970-2006; such an effect is shown to be stronger for those countries which have a larger stock of migrants abroad. Naudé and Bezuidenhout (2014), instead, focus their analysis on Sub-Saharan Africa and show that the responsiveness of remittances to natural disasters in the region seems to be higher - although very slow - compared to what happens following other human-caused types of catastrophes like armed conflicts or global financial crises.

\footnotetext{
${ }^{3}$ Among others, see Attzs (2008), Halliday (2006), Harvey and Savage (2007) and Weiss Fagen (2004), with regard to Central America, Yang and Choi (2007), Wu (2006) and Le De, Gaillard, and Friesen (2015), with regard to South Asia.

${ }^{4} \mathrm{~A}$ related strand of literature have documented that migrants' remittance transfers contribute to mitigate vulnerability of developing countries to adverse food-price shocks and global financial crises (Sirkeci, Cohen, and Ratha, 2012; Combes, Ebeke, Etoundi, and Yogo, 2014) and to sustain efforts for reconstruction from armed conflicts(Harris and Terry, 2013; Naudé and Bezuidenhout, 2014).
} 
A positive role of remittances in dampening the destabilizing effect of natural disasters on output volatility has been highlighted by Ebeke and Combes (2013). However, they show that macroeconomic instability following natural disasters is likely to be fostered by remittance inflows due to inflation dynamics and moral hazard effects on recipient households when the remittance/GDP ratio is above a certain threshold (17\%).

In this paper, we build on the existing empirical literature to offer further systematic evidence on the impact that natural disasters may have on remittance flows towards lowand middle-income (LMIC) countries. Our perspective is much wider than that adopted by Yang (2008) both in terms of geographic coverage and the type of disasters considered. Following David (2011) and Mohapatra, Joseph, and Ratha (2012) we do not simply focus on a single type of disaster but consider all weather-related types of disasters together with geophysical disruptive events. However, compared to the cross-country evidence provided in these two latter contributions, the present study does not focus exclusively on the ex post contribution of remittances to the reconstruction process but also takes into account their role in terms of ex ante risk preparedness. To the best of our knowledge, this is the first attempt to investigate the twofold (ex-ante and ex-post) role remittances can play at the aggregate level.

A second fresh contribution of this paper is to investigate whether the financial development of the country hit by a natural disaster plays a role in affecting the response of remittances to such an adverse event. The relationship between remittances and financial development has been analyzed in the literature both indirectly, by looking at how they interact in promoting economic growth (Giuliano and Ruiz-Arranz, 2009; Mundaca, 2009; Ahamada and Coulibaly, 2011; Bettin and Zazzaro, 2012), and directly, by analyzing to what extent remittances contribute to financial development (Gupta, Pattillo, and Wagh, 2009; Aggarwal, Demirgüç-Kunt, and Pería, 2011; Demirgüç-Kunt, Córdova, Pería, and Woodruff, 2011; Brown, Carmignani, and Fayad, 2013; Coulibaly, 2015) and to what extent the reverse holds true (Mookerjee and Roberts, 2011; Bettin, Lucchetti, and Zazzaro, 2012; Bang, Mitra, and Wunnava, 2013).

In the presence of a better developed financial sector, the amount of credit available at the local level would be higher, thus representing a fundamental resource to recover from natural disasters. Therefore, we could expect the scope for altruistic and insurancemotivated remittances to narrow in countries with an efficient banking sector, as Arezki and Brückner (2012) indeed show for Sub-Saharan Africa. Similarly, evidence has been provided that access to credit might tighten up after a disaster, especially in the absence of relationship lending (Berg and Schrader, 2012), and remittances then are likely to act as a substitute for local credit where financial development is low. However, taking part in the reconstruction process might yield high returns to private investments, which are likely to be safer in countries with a more efficient banking sector. Complementarity would then be observed between investment-driven remittances and financial development in the presence of higher incidence/risk of natural disasters. 
We consider a panel of 98 LMIC countries for the period 1990-2010 and estimate a model on the determinants of aggregate remittance inflows by means of the system GMM estimator. The empirical specification captures both the ex post immediate response after a disaster and the ex ante insurance mechanism, due to long-term exposure to natural catastrophes. In order to control for the role of local financial development, we include different measures of the size of the banking sector and augment the baseline specification by taking into account the interaction between proxies for natural disasters and financial development variables.

By way of preview, our results provide evidence of a positive ex post response of remittances to natural disasters, thus supporting either altruistic or profit-driven motivations behind international transfers. At the same time, insurance mechanisms might be at work since remittances prove significantly higher toward countries that experienced more disruptive events in the past. When taking into account the interaction with the level of development of the local financial sector, remittances seem to substitute for less efficient financial systems both in terms of ex post response to disasters and in terms of ex ante risk management strategy. This result might be read as indirect evidence of altruistic feelings driving remittance sensitivity to natural catastrophes.

The rest of the paper is organized as follows: section 2.1 describes the data and offers some descriptive evidence on the incidence of weather-related disasters in our sample. Section 2.2 presents the empirical specification and our estimation strategy. Section 3 discusses results in detail while Section 4 concludes.

\section{The empirical strategy}

\subsection{Data on natural disasters}

The International Emergency Disasters Database (EM-DAT) updated since 1988 by the Centre for Research on the Epidemiology of Disasters (CRED) is the main international source on natural disasters data. ${ }^{5}$ Information refers to the occurrence and intensity of different types of disasters from 1900 to the present with worldwide coverage, and is gathered from multiple sources: UN agencies, research institutes, non-governmental organizations, insurance companies, press agencies. According to EM-DAT, a disaster is a "situation or event, which overwhelms local capacity, necessitating a request to national or international level for external assistance" ${ }^{6}$

Out of the different types of disasters surveyed by CRED, we take into account those potentially induced by climatic variability together with geophysical events, as described

\footnotetext{
${ }^{5}$ The dataset is publicly accesible at http:/ / www.cred.be/emdat/.

${ }^{6}$ Formally, an event is classified as a disaster and enters the database whenever it fulfills at least one out of four selection criteria: ten or more people killed; 100 or more people affected, injured or homeless following the disaster; declaration of a state of emergency; call for international assistance. See http://www.emdat.be/criteria-and-definition.
} 
in Table 1, and aggregate information on the subgroups of events to obtain a single country-level indicator for disasters. In particular, from the EM-DAT database we draw information for the number of disastrous events, the total number of people affected and the total amount of direct damage per year from 1970 to 2010 in order to construct our variables of interest.

Table 1: Disaster groups considered in the analysis

\begin{tabular}{ll}
\hline Disaster subgroup & Disaster main types \\
\hline Meteorological & Storm \\
Hydrological & Flood, Mass movement (wet) \\
Climatological & Extreme Temperature, Drought, Wildfire \\
Geophysical & Earthquake, Volcano eruption, mass movement (dry) \\
\hline
\end{tabular}

Figure 1 shows a general upward trend in the number of disasters across regions in the period 1990-2010. The East Asia and Pacific region and Latin America and the Caribbean have been hit particularly hard by catastrophic events in recent decades but the frequency of disasters has also significantly increased in Sub-Saharan Africa.

Figure 1: Number of natural disasters by region, 1990-2010

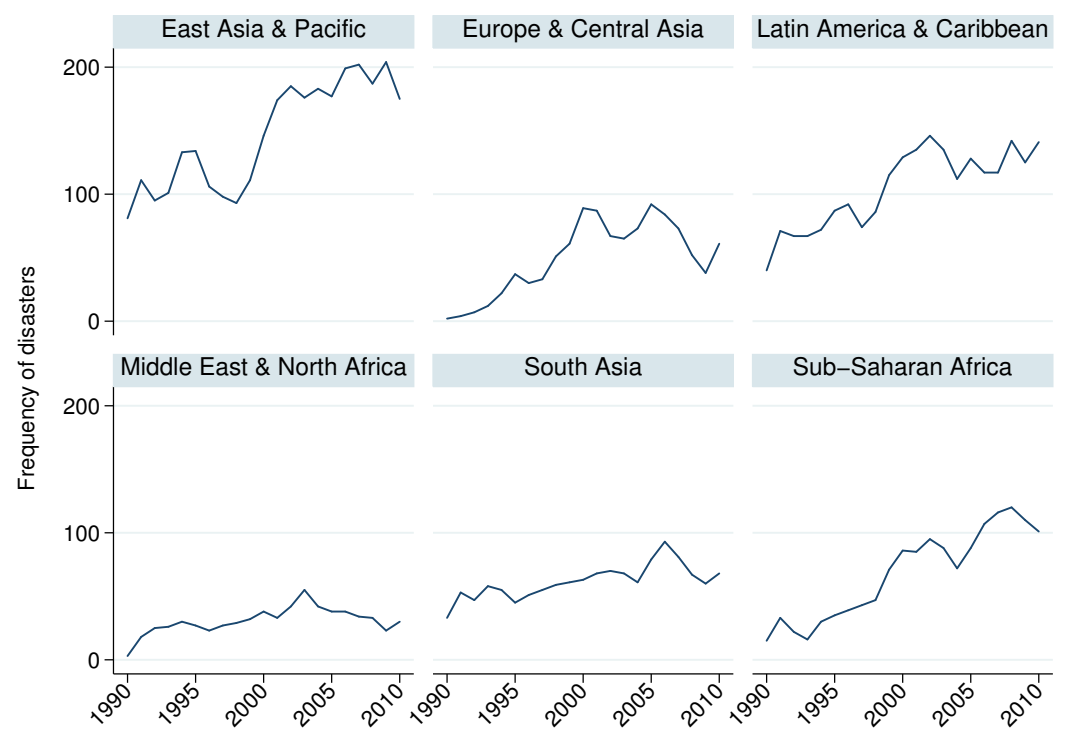

Source: authors' calculations on EM-DAT database, CRED.

The share of the population affected by disasters and the damage caused display great variability both across regions and over time (Figure 2). In Sub-Saharan Africa, economic losses (as a percentage of GDP) are much lower than the share of total population affected by disasters; this probably reflects how difficult it is to estimate damage in countries where most of the population lives in poverty and suffers from severe material deprivation. In contrast, in the small, tourist-based economies of Central and Latin 
Figure 2: Share of population affected and damage by region, 1990-2010

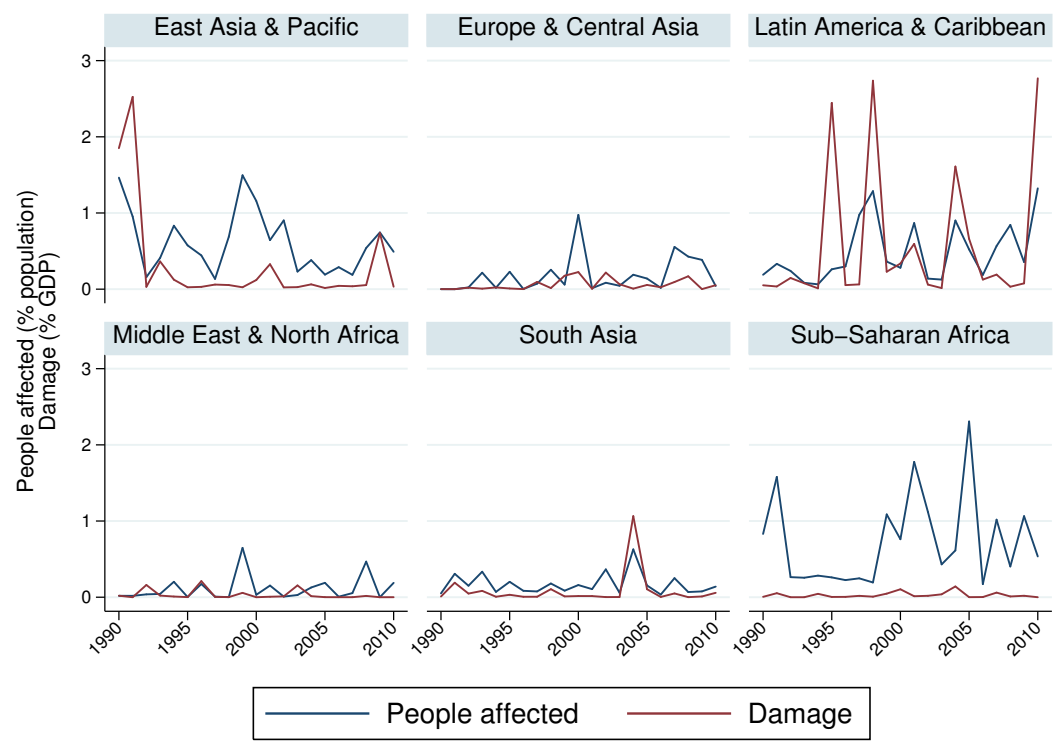

Source: authors' calculations on EM-DAT database, CRED.

America the consequences of disasters prove much stronger in terms of economic losses than population affected.

\subsection{The estimated model}

Our empirical strategy is based on the estimation of the following baseline model:

$$
\begin{aligned}
\operatorname{REM}_{i, t}= & \alpha_{1} * D I S_{i, t}+\alpha_{2} * D I S_{i, t-1}+\beta_{1} * E X P_{i, t}+\gamma * R E M_{i, t-1}+ \\
& +\delta * X_{i, t-1}+\mu_{i}+\tau_{t}+\epsilon_{i, t}
\end{aligned}
$$

where the dependent variable $R E M_{i, t}$ represents the logarithm of total remittance inflows to country $i$ at time $t$. The basic set of control variables $X_{i, t-1}$ includes: the lagged value of the dependent variable $(R E M)$; the logarithm of the total stock of migrants from country $i$ residing in the OECD area, to control for the number of potential senders $(M I G)^{7}$; the logarithm of GDP per capita (GDP $P C$ ) and its square, to control for possible nonlinear effects of receiving household income on remittances. We then control for the logarithm of the net per capita official development aid received by country $i(A I D)$ to take into account the fact that the responsiveness of remittances to natural disasters might be limited if a country can rely on increased international assistance. The level of financial development is proxied either by private credit from deposit money banks to GDP (CRED) or by bank deposits to GDP (DEP). All other country-level characteristics are taken into

\footnotetext{
${ }^{7}$ Since annual country-level data on the overall size of the diaspora are not available, we use the total number of migrants residing in OECD countries to proxy for it.
} 
account by including country fixed effects $\mu_{i}$ while common time effects are captured by $\tau_{t}$.

Data on remittances, GDP per capita and official development aid are taken from the World Development Indicators (WDI); data on the migrant stocks come from the OECD International Migration Database. ${ }^{8}$ Financial development data are from the World Bank Financial Development and Structure Dataset (Beck, Demirgüc-Kunt, and Levine, 2000, 2009; Cihak, Demirguc-Kunt, Feyen, and Levine, 2012). Definition, data sources and descriptive statistics of all the variables in our model are reported in Table 5.

Our main variables of interest are those related to natural disasters. In the baseline specification, the disaster variable is expressed as a dummy $D I S_{i, t}$, which takes value 1 if country $i$ experienced at least one natural disaster at time $t-1$ or $t$. In this way, we test for ex-post short and very short term responsiveness of remittances to disasters: other things being equal, a positive sign on $\alpha_{1}$ could in fact hint at the role that transfers from abroad might have in contributing to the reconstruction process after a disaster. Along the same lines, to account for remittances' medium term responsiveness to disasters, we also include $D I S_{i, t-1}$, which takes value 1 if country $i$ experienced at least one natural disaster at time $t-2$ or $t-3$.

To test whether remittances may also be part of an ex ante household-level insurance strategy against future adverse income shocks produced by natural disasters, we add $E X P_{i, t}$ to the estimated specification, which represents the average past probability of being affected by a disaster in country $i$. This variable is constructed as the average number of past natural disasters that hit the country between 1970 and $t-5$, in order to avoid any overlapping effect with the ex-post responsiveness to disasters. ${ }^{9}$ The role of remittances as an ex ante risk management strategy would imply $\beta_{1}>0$.

In order to test the robustness of ex-post remittance reaction to natural disasters, we employ different indicators to proxy for the intensity of such events: beside the simple dichotomous variable, we alternatively include the annual frequency of disaster events in country $i(N D I S)$, the share of damage on GDP (DAMAGE) or the share of people affected on the total population (POP_AFFECT). All three disaster proxies are expressed at time $t$ (as averages between time $t$ and $t-1$ ) and lagged at $t-1$ (as averages between time $t-2$ and $t-3)$.

The estimated specification in Equation 1 is then augmented to include the interaction between disaster variables and the level of financial development:

\footnotetext{
${ }^{8}$ The database is accessible at http://stats.oecd.org/Index.aspx?DatasetCode=MIG.

${ }^{9}$ Alternatively, we built EXPOSURE by considering the average number of disasters in the period between 1970 and $t-3$, with no appreciable differences in estimation results.
} 


$$
\begin{aligned}
R E M_{i, t}= & \alpha_{1} * D I S_{i, t}+\alpha_{2} * D I S_{i, t-1}+\alpha_{3} *\left(D I S_{i, t} * F I N D E V_{i, t}\right)+ \\
& +\alpha_{4} *\left(D I S_{i, t-1} * F I N D E V_{i, t}\right)+\beta_{1} * E X P_{i, t}+\beta_{2} *\left(E X P_{i, t} * F I N D E V_{i, t}\right)+ \\
& +\gamma * R E M_{i, t-1}+\delta * X_{i, t-1}+\mu_{i}+\tau_{t}+\epsilon_{i, t}
\end{aligned}
$$

The sign on the interaction coefficients $\alpha_{3}, \alpha_{4}$ and $\beta_{2}$ could tell us whether remittances may act as substitutes of the internal financial sector in the case of natural disasters. More specifically, a negative sign on $\alpha_{3}$ and $\alpha_{4}$ would imply higher ex post remittances toward countries with less developed financial systems, where people cannot rely on resources borrowed from financial intermediaries for the reconstruction process. Such a result would be thoroughly in line with altruistic feelings as motivations to remit. On the other hand, a positive sign on $\alpha_{3}$ and $\alpha_{4}$ means that remittance inflows are larger in better developed financial systems, possibly unveiling the willingness to channel savings into profitable investments in the post-disaster phase. A negative sign on $\beta_{2}$ would reinforce the hypotheses that remittances substitute for formal finance in countries where the latter is not well established. Migrants from the most severely affected regions might anticipate the future need of their families at home in the event of natural disasters: the lower the chance of borrowing resources from the banking sector, the larger the amount they will send back home.

Equation 1 is estimated by using the Arellano and Bover (1995) two-step system GMM estimator (Roodman, 2009). This allows us to address persistence in remittance series, together with the bias deriving from the possible endogeneity of per capita GDP and financial development. ${ }^{10}$ The time period considered in the estimation is 1991-2010, since we have data on migrant stocks only starting from 1990. The sample includes 98 low- and middle-income countries listed in Table 6.

\section{Results and main findings}

\subsection{Baseline estimates}

In Table 2 we report regression results for our baseline specification using the SGMM estimator. ${ }^{11}$ Our sample includes 98 countries listed in Table 6 and 1528 observations. Column 1 shows the basic specification which includes standard determinants of remittance flows usually considered in the literature. Remittances are extremely persistent over time, as shown by the positive and highly significant coefficient on the lagged value

\footnotetext{
${ }^{10}$ All specifications include two lags of remittances, financial development and per capita GDP as instruments.

${ }^{11}$ The result of the Hansen test of overidentifying restrictions shows that the moment conditions assumed for GMM estimation are valid. Moreover, the AR2 test rejects the presence of second order serial correlation.
} 
Table 2: Baseline results

\begin{tabular}{|c|c|c|c|c|}
\hline & $(1)$ & $(2)$ & (3) & $(4)$ \\
\hline DISASTER $_{t, t-1}$ & & $\begin{array}{l}0.287^{* *} \\
{[0.123]}\end{array}$ & $\begin{array}{l}0.235^{* *} \\
{[0.100]}\end{array}$ & $\begin{array}{l}0.221^{* *} \\
{[0.097]}\end{array}$ \\
\hline DISASTER $_{t-2, t-3}$ & & $\begin{array}{c}0.274^{* * *} \\
{[0.105]}\end{array}$ & $\begin{array}{c}0.157^{*} \\
{[0.086]}\end{array}$ & $\begin{array}{c}0.138^{*} \\
{[0.080]}\end{array}$ \\
\hline EXPOSURE & & $\begin{array}{c}0.145^{* * *} \\
{[0.055]}\end{array}$ & $\begin{array}{c}0.172^{* * *} \\
{[0.059]}\end{array}$ & $\begin{array}{c}0.195^{* * *} \\
{[0.061]}\end{array}$ \\
\hline $\operatorname{REM}_{t-1}$ & $\begin{array}{c}0.536^{* * *} \\
{[0.167]}\end{array}$ & $\begin{array}{c}0.547^{* * *} \\
{[0.146]}\end{array}$ & $\begin{array}{c}0.507^{* * *} \\
{[0.111]}\end{array}$ & $\begin{array}{c}0.483^{* * *} \\
{[0.120]}\end{array}$ \\
\hline MIG & $\begin{array}{c}0.271^{* * *} \\
{[0.105]}\end{array}$ & $\begin{array}{c}0.207^{* * *} \\
{[0.073]}\end{array}$ & $\begin{array}{l}0.127^{* *} \\
{[0.058]}\end{array}$ & $\begin{array}{l}0.139^{* *} \\
{[0.069]}\end{array}$ \\
\hline GDP PC & $\begin{array}{c}2.274^{* * *} \\
{[0.877]}\end{array}$ & $\begin{array}{l}2.295^{* *} \\
{[0.910]}\end{array}$ & $\begin{array}{c}2.649 * * * \\
{[0.730]}\end{array}$ & $\begin{array}{c}2.374^{* * *} \\
{[0.850]}\end{array}$ \\
\hline GDP PC ${ }^{2}$ & $\begin{array}{c}-0.165^{* *} \\
{[0.066]}\end{array}$ & $\begin{array}{c}-0.165^{* *} \\
{[0.068]}\end{array}$ & $\begin{array}{c}-0.198^{* * *} \\
{[0.055]}\end{array}$ & $\begin{array}{c}-0.175^{* * * *} \\
{[0.062]}\end{array}$ \\
\hline AID & $\begin{array}{l}-0.267 \\
{[0.220]}\end{array}$ & $\begin{array}{c}-0.275 \\
{[0.208]}\end{array}$ & $\begin{array}{c}-0.103 \\
{[0.179]}\end{array}$ & $\begin{array}{l}-0.167 \\
{[0.194]}\end{array}$ \\
\hline DEPOSIT & & & $\begin{array}{l}2.138^{* *} \\
{[0.928]}\end{array}$ & \\
\hline CREDIT & & & & $\begin{array}{l}1.318^{* *} \\
{[0.614]}\end{array}$ \\
\hline Observations & 1,528 & 1,528 & 1,528 & 1,528 \\
\hline Number of ctycode & 98 & 98 & 98 & 98 \\
\hline Hansen test ( $\mathrm{p}$-value) & 0.165 & 0.205 & 0.307 & 0.204 \\
\hline AR1 test ( $\mathrm{p}$-value) & 0.003 & 0.002 & 0.004 & 0.006 \\
\hline AR2 test ( $p$-value) & 0.438 & 0.703 & 0.770 & 0.598 \\
\hline Joint test disasters ( $\mathrm{p}$-value) & & 0.039 & 0.026 & 0.016 \\
\hline
\end{tabular}

Notes: The table reports regression coefficients and (in brackets) the associated robust standard errors. * significant at $10 \%$; ${ }^{* *}$ significant at 5\%; ${ }^{* * *}$ significant at 1\%. Estimations are carried out by using the System GMM estimator (Arellano and Bover, 1995). The dependent variable is the logarithm of total official remittances at constant prices to country $i$ in year $t\left(R E M_{i, t}\right)$. A constant and a set of year $(t)$ dummies are included. Two lags of all potentially endogenous variables have been included as instrumnents. P-values for first and second order autocorrelation and for the Hansen test are reported. In addition, we show the p-value for a Wald test of joint significance of all disaster-related variables in each specification. 
at time $t-1$ (Mohapatra, Joseph, and Ratha, 2012). A larger diaspora abroad is associated to larger remittance flows (Docquier, Rapoport, and Salomone, 2012; Freund and Spatafora, 2008), while our results provide evidence of non-linear effects of GDP per capita. Transfers increase with the level of economic development of the recipient country but after a certain threshold, which is very close to the average value of GDP per capita in our sample ${ }^{12}$, the sign of this relationship becomes negative. There are no significant effects of official aids on remittances, although it is interesting to highlight that the coefficient is constantly negative across all specifications (Amuedo-Dorantes, Pozo, and Vargas-Silva, 2007; Bettin, Presbitero, and Spatafora, 2016). Proxies for financial development have a positive and significant effect (Table 2, columns 3-4) showing that countries with better developed financial systems attract larger flows of transfers from their migrants abroad (Bettin, Lucchetti, and Zazzaro, 2012; Mookerjee and Roberts, 2011).

Column 2-4 include our variables of interest related to natural disasters. DIS ASTER $R_{t, t-1 \text {, }}$ is a dummy equal to one if the country experienced at least one disaster in year $t$ or $t-1$, while DISASTER $R_{t-2, t-3}$ takes value one if at least one disaster took place in year $t-2$ or $t-3$. The response of remittances to natural disasters is positive both in the very short $\left(D I S A S T E R_{t, t-1}\right)$ and in the short term $\left(D_{\text {ISASTER }}-2, t-3\right)$. Remittances increase in the aftermath of a disaster to contribute to the reconstruction process, although this effect seems to weaken over time. All other things being equal, remittances received by countries that were hit by a catastrophe in the current or previous year are $33 \%$ larger (column 2) than those received by countries not affected by natural shocks. ${ }^{13}$ The impact of disasters is still significant as much as two or three years later, with transfers to affected countries being 31\% larger compared to non-affected countries. The joint test on disaster variables reported in the last row of Table 2 confirms that both the ex ante and ex post impact of natural disasters on remittances are significant across the different specifications.

We explicitly test whether remittances contribute to ex ante risk preparedness (EXPO$S U R E$ ) and find that transfers significantly increase with the average number of past natural disasters in the country between 1970 and $t-5$. Experiencing an additional shock in the past raises remittances by roughly $14 \%$. The role of remittances as part of an ex ante risk management strategy is extremely robust across all specifications. Migrants that come from countries that were particularly exposed to disasters are likely to take into account the higher risk their relatives back home need to face and provide them with a sort of informal insurance that might be of help in case of future damages.

When including different proxies (DEPOSIT or CREDIT) for financial development in the baseline model (Table 2, columns 3-4), disaster variables are still positive and significant. Remittances increase in the aftermath of a disaster to contribute to the reconstruc-

\footnotetext{
${ }^{12}$ In Table 2, column 1, for example, the threshold is equal to 6.9 (in natural logarithm), while the sample mean is 7.01 .

${ }^{13}$ The formula to compute this effect is $\left(e^{\alpha_{1}}-1\right) * 100 \%$, where $\alpha_{1}$ is the coefficient associated to DISASTER $R_{t, t-1}$ in Equation 1.
} 
tion process, although this effect becomes smaller in magnitude once we take financial development into account. In particular, the response of remittances seems to weaken more rapidly over time. According to estimates in column 3, remittances received by countries that were hit by a disaster in $t$ or $t-1(t-2$ or $t-3)$ are $26 \%(17 \%)$ larger than those received by countries not affected by any shock. At the same time, the size of the coefficient on past disasters (EXPOSURE) slightly increases when including financial development variables. These findings suggest that financial development makes the flow of remittances in the aftermath of a disaster of a less crucial importance for recovery, while it allows strategies of preparedness to risk of future disaster to be pursued more effectively.

\subsection{Interaction with financial development}

Table 3 shows results for the augmented specification in Equation 2, when the interaction between the level of financial development and the disaster variable is also included in the estimated model. Estimates are qualitatively similar if financial development is proxied with either banks' deposits to GDP (column 1) or private credit by deposit money banks to GDP (column 2).

All interaction terms have a negative sign, thus meaning that remittances act as substitutes for less developed financial systems in response to natural disasters. If emergency loans cannot be provided by the local banking sector due to lending restrictions after natural shocks (Berg and Schrader, 2012), the additional extraordinary demand for financial resources would be likely satisfied through international remittance transfers.

The substitution effect seems even stronger when interacting financial variables with past exposure to natural disasters. Households that live in the most affected areas might anticipate risks ahead and ask their members abroad to provide them with an informal insurance against future shocks if they cannot rely on a well functioning financial system that might be of support after a disaster.

In terms of ex post contribution to the reconstruction process, the substitution relationship between remittances and financial development seems to hold in the very short term, while it becomes less evident over time. The ex post response to a disaster that took place in year $t$ or $t-1$ is positive and significant at the $5 \%$ level up to the median level of financial development in our sample (Figure 3, panel a) but gets weaker when considering disasters that hit the country two or three years before (Figure 3, panel b). At the same time, a significant and positive effect of past exposure to natural disasters holds up to the $75^{\text {th }}$ percentile of financial development (Figure 3, panel c).

Other things being equal, for the median country in our sample (in terms of bank deposits to GDP) experiencing natural disasters in the current or in the previous year increases remittances received by $27 \%$ (Table 3, column 1 ). In terms of ex ante risk management strategy a $10 \%$ rise in the frequency of past disasters raises remittances by $24 \%$. 
Table 3: Interaction with financial development

\begin{tabular}{|c|c|c|}
\hline & $(1)$ & $(2)$ \\
\hline DISASTER $_{t, t-1}$ & $\begin{array}{l}0.480^{* *} \\
{[0.211]}\end{array}$ & $\begin{array}{c}0.557^{* * *} \\
{[0.198]}\end{array}$ \\
\hline DISASTER $_{t-2, t-3}$ & $\begin{array}{l}0.394^{*} \\
{[0.218]}\end{array}$ & $\begin{array}{l}0.440^{* *} \\
{[0.182]}\end{array}$ \\
\hline EXPOSURE & $\begin{array}{c}0.376^{* * *} \\
{[0.126]}\end{array}$ & $\begin{array}{c}0.279 * * * \\
{[0.086]}\end{array}$ \\
\hline DEPOSIT & $\begin{array}{l}2.191^{*} \\
{[1.314]}\end{array}$ & \\
\hline CREDIT & & $\begin{array}{l}3.311^{* *} \\
{[1.471]}\end{array}$ \\
\hline DISASTER $_{t, t-1}{ }^{*}$ DEPOSIT & $\begin{array}{l}-0.931 \\
{[0.634]}\end{array}$ & \\
\hline DISASTER $_{t, t-1}{ }^{*}$ CREDIT & & $\begin{array}{c}-1.298^{* *} \\
{[0.605]}\end{array}$ \\
\hline DISASTER $_{t-2, t-3}{ }^{*}$ DEPOSIT & $\begin{array}{l}-0.790 \\
{[0.605]}\end{array}$ & \\
\hline DISASTER $_{t-2, t-3}{ }^{*}$ CREDIT & & $\begin{array}{c}-1.144^{* *} \\
{[0.581]}\end{array}$ \\
\hline EXPOSURE*DEPOSIT & $\begin{array}{c}-0.513^{* *} \\
{[0.237]}\end{array}$ & \\
\hline EXPOSURE*CREDIT & & $\begin{array}{l}-0.328^{*} \\
{[0.177]}\end{array}$ \\
\hline $\operatorname{REM}_{t-1}$ & $\begin{array}{c}0.638^{* * *} \\
{[0.163]}\end{array}$ & $\begin{array}{c}0.545^{* * *} \\
{[0.116]}\end{array}$ \\
\hline MIG & $\begin{array}{c}0.059 \\
{[0.077]}\end{array}$ & $\begin{array}{c}0.103 \\
{[0.067]}\end{array}$ \\
\hline GDP PC & $\begin{array}{l}3.048^{* * *} \\
{[0.800]}\end{array}$ & $\begin{array}{c}2.781^{* * *} \\
{[0.781]}\end{array}$ \\
\hline GDP PC ${ }^{2}$ & $\begin{array}{c}-0.222^{* * *} \\
{[0.059]}\end{array}$ & $\begin{array}{c}-0.203^{* * *} \\
{[0.057]}\end{array}$ \\
\hline AID & $\begin{array}{c}-0.210 \\
{[0.167]}\end{array}$ & $\begin{array}{l}-0.142 \\
{[0.179]}\end{array}$ \\
\hline Observations & 1,528 & 1,528 \\
\hline Number of ctycode & 98 & 98 \\
\hline Hansen test ( $\mathrm{p}$-value) & 0.163 & 0.234 \\
\hline AR1 test (p-value) & 0.004 & 0.003 \\
\hline AR2 test ( $p$-value) & 0.723 & 0.966 \\
\hline Joint test disasters ( $\mathrm{p}$-value) & 0.042 & 0.015 \\
\hline
\end{tabular}

Notes: The table reports regression coefficients and (in brackets) the associated robust standard errors. ${ }^{*}$ significant at $10 \%$; ${ }^{* *}$ significant at 5\%; ${ }^{* * *}$ significant at $1 \%$. Estimations are carried out by using the System GMM estimator (Arellano and Bover, 1995). The dependent variable is the logarithm of total official remittances at constant prices to country $i$ in year $t\left(R E M_{i, t}\right)$. A constant and a set of year $(t)$ dummies are included. Two lags of all potentially endogenous variables have been included as instrumnents. P-values for first and second order autocorrelation and for the Hansen test are reported. In addition, we show the p-value for a Wald test of joint significance of all disaster-related variables in each specification. 
Figure 3: Impact of disaster variables at different level of financial development

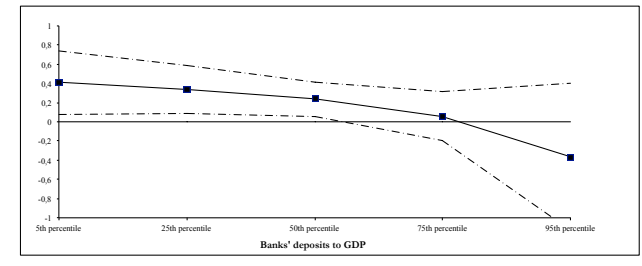

(a) DISASTER $R_{t, t-1}$

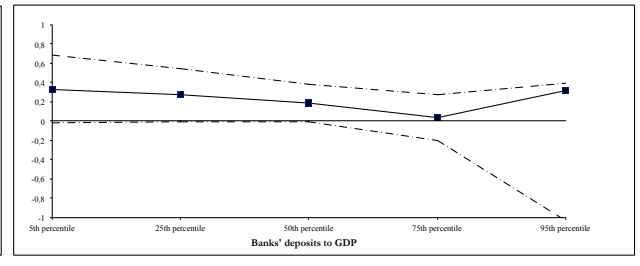

(b) DISASTER $R_{t-2, t-3}$

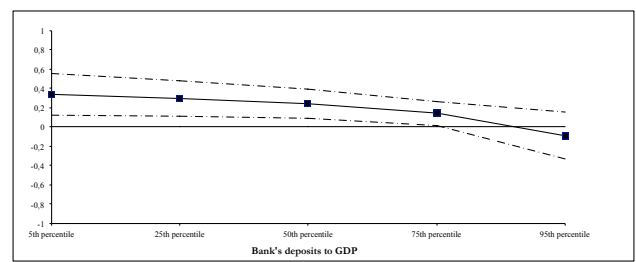

(c) EXPOSURE

Note: marginal effects reported on the y axis. Marginal effects and 95\% confidence interval calculations based on estimates in Table 3, column 1. Financial development proxied as banks' deposits to GDP.

\subsection{Alternative measures for natural disasters}

Natural disasters can be proxied through different measures that take into account either the frequency or the intensity of such events rather than their occurrency, captured through the dummy DISASTER in our baseline model. Results for the augmented specification with the interaction between different proxies for natural disasters and financial development are reported in Table 4.

Irrespective of the measure for natural disasters, the traditional determinants of remittances are in most cases still significant, with the expected sign. The positive effect of past exposure to natural disasters is also strongly robust, as well as its negative interaction with the level of financial development.

In the first two columns of Table 4, we employ the frequency of disaster events in the very short $\left(N_{-} D I S_{t, t-1}\right)$ or in the short term $\left(N_{-} D I S_{t-2, t-3}\right)$. The ex post response of remittances is still positive and significant, but only up to one year after the disaster. An additional disaster in $t$ or $t-1$ increases remittances received by $0.8 \%$ at the median level of financial development in our sample (Table 4, column 1). Using the same proxy, David (2011) showed that remittances increase in the very short term (same or following year) after either climatic or geological disasters and such effects are similar in magnitude to our estimated coefficients.

Alternatively, we consider two proxies for the intensity of adverse natural events: the annual share of total population affected by disasters (POP_AFFECT, column 3-4) and the total yearly damage as a share of GDP caused by natural disasters (DAMAGE, column 5-6) in each country. These two proxies might not be fully exogenous to actual and 
past remittance flows, and this may explains why related coefficients are consistently positive, but not always display a significant impact on aggregate remittance inflows. Mohapatra, Joseph, and Ratha (2012) used the same measures to proxy for the intensity of natural events and showed that remittances significantly increase in response to disasters only in countries with a large enough diaspora abroad. Yang (2008) also provided evidence for an increase in remittances to poor countries that were hit by a hurricane up to three years before although his index for the intensity of the storm was directly computed by means of meteorological data.

It is worth noting that the negative sign on the interaction between the level of financial development (DEPOSIT or CREDIT) and disaster variables is extremely robust to the use of different proxies for the intensity of natural events. This additional evidence confirms that countries with less developed financial systems might rely on their diaspora abroad to substitute for financial resources not readily available at the local level for supporting the reconstruction process. However, this substitution mechanism is significantly at work only in the immediate aftermath of a disaster, while no significant impact seems to persist in the following years.

\section{Conclusions}

Remittances nowadays represent an important source of capital for poor countries. Besides their likely contribution to economic development, the recent literature has also investigated whether and to what extent these transfers mitigate the effects of different types of macroeconomic shocks affecting migrants' countries of origin (Sirkeci, Cohen, and Ratha, 2012; Harris and Terry, 2013; Combes, Ebeke, Etoundi, and Yogo, 2014; Naudé and Bezuidenhout, 2014).

The aim of this paper was to shed further light on the way remittances from the diaspora abroad react to natural disasters in low- and middle-income countries. We departed from the scant existing evidence which focuses on the ex-post contribution of remittances to the reconstruction process by explicitly considering also their role in terms of ex ante risk preparedness.

In addition, the interplay between remittances and financial development has been taken into account to understand whether, despite the occurrence of natural disasters, altruistic and insurance-motivated transfers narrow for countries with a well developed banking sector, while increasing where local credit is not readily available.

Estimates carried out on a sample of 98 LMIC countries for the period 1990-2010 showed that remittances increase in the aftermath of a disaster to help affected areas with the reconstruction process but their role becomes of a less crucial importance in countries with an efficient banking sector. The negative sign on the interaction term between disaster variables and financial development indeed called for a substitution mechanism: remittances act as substitutes for less developed financial systems which are not able to 
Table 4: Different proxies for natural disasters

\begin{tabular}{|c|c|c|c|c|c|c|}
\hline & $\begin{array}{c}(1) \\
\text { DEPOSIT }\end{array}$ & $\begin{array}{c}(2) \\
\text { CREDIT }\end{array}$ & $\begin{array}{c}(3) \\
\text { DEPOSIT }\end{array}$ & $\begin{array}{c}(4) \\
\text { CREDIT }\end{array}$ & $\begin{array}{c}(5) \\
\text { DEPOSIT }\end{array}$ & $\begin{array}{c}\text { (6) } \\
\text { CREDIT }\end{array}$ \\
\hline $\mathrm{N}_{\mathrm{N}} \mathrm{DIS}_{t, t-1}$ & $\begin{array}{c}0.054^{* * *} \\
{[0.015]}\end{array}$ & $\begin{array}{l}0.037^{* *} \\
{[0.015]}\end{array}$ & & & & \\
\hline $\mathrm{N}_{-} \mathrm{DIS}_{t-2, t-3}$ & $\begin{array}{c}0.015 \\
{[0.016]}\end{array}$ & $\begin{array}{c}0.021 \\
{[0.014]}\end{array}$ & & & & \\
\hline POP_AFFECT $T_{t, t-1}$ & & & $\begin{array}{c}0.789 \\
{[0.491]}\end{array}$ & $\begin{array}{c}0.302 \\
{[0.350]}\end{array}$ & & \\
\hline POP_AFFECT $T_{t-2, t-3}$ & & & $\begin{array}{l}0.830^{*} \\
{[0.435]}\end{array}$ & $\begin{array}{c}0.311 \\
{[0.266]}\end{array}$ & & \\
\hline DAMAGE $_{t, t-1}$ & & & & & $\begin{array}{c}0.205 \\
{[0.170]}\end{array}$ & $\begin{array}{l}0.298^{* *} \\
{[0.131]}\end{array}$ \\
\hline DAMAGE $_{t-2, t-3}$ & & & & & $\begin{array}{c}0.095 \\
{[0.136]}\end{array}$ & $\begin{array}{c}0.073 \\
{[0.105]}\end{array}$ \\
\hline EXPOSURE & $\begin{array}{l}0.343^{* *} \\
{[0.136]}\end{array}$ & $\begin{array}{l}0.238^{* *} \\
{[0.093]}\end{array}$ & $\begin{array}{c}0.566^{* * *} \\
{[0.189]}\end{array}$ & $\begin{array}{c}0.411^{* * *} \\
{[0.147]}\end{array}$ & $\begin{array}{l}0.566^{* * *} \\
{[0.184]}\end{array}$ & $\begin{array}{c}0.416^{* * *} \\
{[0.143]}\end{array}$ \\
\hline FINDEV & $\begin{array}{l}1.775^{* *} \\
{[0.846]}\end{array}$ & $\begin{array}{l}1.722^{* *} \\
{[0.872]}\end{array}$ & $\begin{array}{l}1.985^{* *} \\
{[0.963]}\end{array}$ & $\begin{array}{l}2.247^{*} \\
{[1.211]}\end{array}$ & $\begin{array}{l}1.798^{* *} \\
{[0.877]}\end{array}$ & $\begin{array}{l}2.168^{*} \\
{[1.140]}\end{array}$ \\
\hline N_DIS $_{t, t-1}{ }^{*}$ FINDEV & $\begin{array}{l}-0.100^{* *} \\
{[0.042]}\end{array}$ & $\begin{array}{c}-0.051 \\
{[0.036]}\end{array}$ & & & & \\
\hline $\mathrm{N}_{-} \mathrm{DIS}_{t-2, t-3}{ }^{*} \mathrm{FINDEV}$ & $\begin{array}{c}0.005 \\
{[0.034]}\end{array}$ & $\begin{array}{c}-0.002 \\
{[0.039]}\end{array}$ & & & & \\
\hline POP_AFFECT $T_{t, t-1}{ }^{*}$ FINDEV & & & $\begin{array}{l}-3.547^{* *} \\
{[1.598]}\end{array}$ & $\begin{array}{l}-2.291^{*} \\
{[1.391]}\end{array}$ & & \\
\hline POP_AFFECT $T_{t-2, t-3}{ }^{*}$ FINDEV & & & $\begin{array}{l}-3.308^{* *} \\
{[1.461]}\end{array}$ & $\begin{array}{l}-1.819 \\
{[1.135]}\end{array}$ & & \\
\hline DAMAGE $_{t, t-1}{ }^{*}$ FINDEV & & & & & $\begin{array}{l}-0.922^{*} \\
{[0.505]}\end{array}$ & $\begin{array}{c}-1.048^{* *} \\
{[0.469]}\end{array}$ \\
\hline DAMAGE $_{t-2, t-3}{ }^{*}$ FINDEV & & & & & $\begin{array}{l}-0.739 \\
{[0.483]}\end{array}$ & $\begin{array}{l}-0.635 \\
{[0.441]}\end{array}$ \\
\hline EXPOSURE*FINDEV & $\begin{array}{c}-0.639^{* *} \\
{[0.305]}\end{array}$ & $\begin{array}{l}-0.421^{*} \\
{[0.220]}\end{array}$ & $\begin{array}{c}-0.966^{* *} \\
{[0.375]}\end{array}$ & $\begin{array}{l}-0.708^{*} \\
{[0.364]}\end{array}$ & $\begin{array}{c}-0.986^{* * *} \\
{[0.377]}\end{array}$ & $\begin{array}{c}-0.728^{* *} \\
{[0.360]}\end{array}$ \\
\hline $\operatorname{REM}_{t-1}$ & $\begin{array}{c}0.629^{* * * *} \\
{[0.148]}\end{array}$ & $\begin{array}{c}0.513^{* * *} \\
{[0.130]}\end{array}$ & $\begin{array}{c}0.647^{* * *} \\
{[0.152]}\end{array}$ & $\begin{array}{c}0.533^{* * *} \\
{[0.123]}\end{array}$ & $\begin{array}{c}0.633^{* * *} \\
{[0.157]}\end{array}$ & $\begin{array}{c}0.523 * * * \\
{[0.123]}\end{array}$ \\
\hline MIG & $\begin{array}{c}0.064 \\
{[0.072]}\end{array}$ & $\begin{array}{c}0.100 \\
{[0.072]}\end{array}$ & $\begin{array}{c}0.027 \\
{[0.080]}\end{array}$ & $\begin{array}{l}0.127^{* *} \\
{[0.063]}\end{array}$ & $\begin{array}{c}0.039 \\
{[0.073]}\end{array}$ & $\begin{array}{l}0.126^{* *} \\
{[0.061]}\end{array}$ \\
\hline GDP PC & $\begin{array}{c}2.801^{* * *} \\
{[0.815]}\end{array}$ & $\begin{array}{c}2.592^{* * *} \\
{[0.762]}\end{array}$ & $\begin{array}{c}3.381^{* * *} \\
{[0.932]}\end{array}$ & $\begin{array}{c}3.035^{* * *} \\
{[0.845]}\end{array}$ & $\begin{array}{c}3.171^{* * *} \\
{[0.904]}\end{array}$ & $\begin{array}{c}2.874^{* * *} \\
{[0.815]}\end{array}$ \\
\hline GDP PC ${ }^{2}$ & $\begin{array}{c}-0.207^{* * *} \\
{[0.059]}\end{array}$ & $\begin{array}{c}-0.191^{* * *} \\
{[0.057]}\end{array}$ & $\begin{array}{c}-0.248^{* * *} \\
{[0.067]}\end{array}$ & $\begin{array}{c}-0.228^{* * *} \\
{[0.063]}\end{array}$ & $\begin{array}{c}-0.234^{* * *} \\
{[0.066]}\end{array}$ & $\begin{array}{c}-0.215^{* * *} \\
{[0.061]}\end{array}$ \\
\hline AID & $\begin{array}{l}-0.178 \\
{[0.167]}\end{array}$ & $\begin{array}{l}-0.157 \\
{[0.182]}\end{array}$ & $\begin{array}{l}-0.175 \\
{[0.177]}\end{array}$ & $\begin{array}{c}-0.192 \\
{[0.172]}\end{array}$ & $\begin{array}{c}-0.175 \\
{[0.172]}\end{array}$ & $\begin{array}{c}-0.175 \\
{[0.173]}\end{array}$ \\
\hline Observations & 1,528 & 1,528 & 1,528 & 1,528 & 1,528 & 1,528 \\
\hline Number of ctycode & 98 & 98 & 98 & 98 & 98 & 98 \\
\hline Hansen test ( $\mathrm{p}$-value) & 0.193 & 0.148 & 0.164 & 0.173 & 0.208 & 0.181 \\
\hline AR1 test ( $p$-value) & 0.005 & 0.006 & 0.004 & 0.006 & 0.005 & 0.007 \\
\hline AR2 test ( $\mathrm{p}$-value) & 0.637 & 0.500 & 0.603 & 0.510 & 0.686 & 0.562 \\
\hline Joint test ( $\mathrm{p}$-value) & 0.001 & 0.033 & 0.132 & 0.079 & 0.024 & 0.021 \\
\hline
\end{tabular}

Notes: The table reports regression coefficients and (in brackets) the associated robust standard errors. * significant at $10 \%$; ${ }^{* *}$ significant at $5 \%$; *** significant at 1\%. Estimations are carried out by using the System GMM estimator (Arellano and Bover, 1995). The dependent variable is the logarithm of total official remittances at constant prices to country $i$ in year $t\left(R E M_{i, t}\right)$. A constant and a set of year $(t)$ dummies are included. Two lags of all potentially endogenous variables have been included as instrumnents. P-values for first and second order autocorrelation and for the Hansen test are reported. In addition, we show the p-value for a Wald test of joint significance of all disaster-related variables in each specification. 
provide local credit for recovering.

Remittances significantly contribute also to $e x$ ante risk preparedness and represent an informal insurance against future damages for people living in areas that have been severely hit by natural disasters in the past. The role of remittances in terms of risk management strategy strengthens in the absence of a well functioning financial system failing to provide financial resources after a disaster. 


\section{References}

ADAM, C. (2013): “Coping with adversity: The macroeconomic management of natural disasters," Environmental Science and Policy, 27, S99-S111.

Aggarwal, R., A. DemirgüÇ-Kunt, And M. S. M. Pería (2011): “Do remittances promote financial development?," Journal of Development Economics, 96(2), 255-264.

AhamadA, I., AND D. Coulibaly (2011): "How does financial development influence the impact of remittances on growth volatility?," Economic Modelling, 28(6), 2748-2760.

Albala-Bertrand, J. M. (1993): Political Economy of Large Natural Disasters: With Special Reference to Developing Countries, no. 9780198287650 in OUP Catalogue. Oxford University Press.

Amuedo-Dorantes, C., S. Pozo, and C. VArgas-Silva (2007): "Remittances and the Macroeconomy: The Case of Small Island Developing States," Working Paper Series UNU-WIDER Research Paper, World Institute for Development Economic Research (UNU-WIDER).

Arellano, M., AND O. Bover (1995): "Another look at the instrumental variable estimation of error-components models," Journal of Econometrics, 68(1), 29-51.

AREZKI, R., AND M. BRÜCKNER (2012): "Rainfall, financial development, and remittances: Evidence from Sub-Saharan Africa," Journal of International Economics, 87(2), 377-385.

AtTzS, M. (2008): “Natural Disasters and Remittances: Exploring the Linkages between Poverty, Gender, and Disaster Vulnerability in Caribbean SIDS," Discussion paper.

BAnG, J. T., A. Mitra, And P. V. WunnaVA (2013): “Financial Liberalization and Remittances: Recent Longitudinal Evidence," IZA Discussion Papers 7497, Institute for the Study of Labor (IZA).

Beck, T., A. DemirgüC-Kunt, And R. Levine (2000): “A New Database on the Structure and Development of the Financial Sector," World Bank Economic Review, 14(3), 597605.

(2009): "Financial institutions and markets across countries and over time - data and analysis," Policy Research Working Paper Series 4943, The World Bank.

BERG, G., AND J. SCHRADER (2012): “Access to credit, natural disasters, and relationship lending," Journal of Financial Intermediation, 21(4), 549-568.

Bettin, G., R. Lucchetti, And A. ZazZaro (2012): “Financial development and remittances: Micro-econometric evidence," Economics Letters, 115(2), 184-186. 
Bettin, G., A. F. Presbitero, and N. L. Spatafora (2016): “Remittances and Vulnerability in Developing Countries," The World Bank Economic Review, forthcoming.

Bettin, G., And A. ZaZZAro (2012): "Remittances and Financial Development: Substitutes or Complements in Economic Growth?," Bulletin of Economic Research, 64(4), 509-536.

Brown, R. P. C., F. Carmignani, and G. Fayad (2013): “Migrants' Remittances and Financial Development: Macro- and Micro-Level Evidence of a Perverse Relationship," The World Economy, 36(5), 636-660.

Cavallo, E., And I. NOY (2009): “The Economics of Natural Disasters: A Survey,” IDB Working Paper Series 124, Inter-American Development Bank, Research Department.

Cihak, M., A. Demirguc-Kunt, E. Feyen, and R. Levine (2012): “Benchmarking financial systems around the world," Policy Research Working Paper Series 6175, The World Bank.

Combes, J.-L., C. EbeKe, M. Etoundi, and T. Yogo (2014): “Are Remittances and Foreign Aid a Hedge Against Food Price Shocks in Developing Countries?," World Development, 54(1), 81-98.

Coulibaly, D. (2015): "Remittances and Financial Development in Sub-Saharan African countries: A System Approach," Economic Modelling, 45(1), 249-258.

DAVID, A. C. (2011): “How do International Financial Flows to Developing Countries Respond to Natural Disasters?," Global Economy Journal, 11(4), 1.

DemirgüÇ-Kunt, A., E. L. Córdova, M. S. M. PeríA, and C. WoOdruff (2011): "Remittances and banking sector breadth and depth: Evidence from Mexico," Journal of Development Economics, 95(2), 229-241.

DOCQUier, F., H. RAPOPORT, AND S. SAlOMONE (2012): “Remittances, migrants' education and immigration policy: Theory and evidence from bilateral data," Regional Science and Urban Economics, 42(5), 817-828.

Drabo, A., And L. M. Mbaye (2011): “Climate Change, Natural Disasters and Migration: An Empirical Analysis in Developing Countries," IZA Discussion Papers 5927, Institute for the Study of Labor (IZA).

EBEKE, C., AND J.-L. COMBES (2013): “Do remittances dampen the effect of natural disasters on output growth volatility in developing countries?," Applied Economics, 45(16), 2241-2254.

Freund, C., AND N. SPATAFORA (2008): “Remittances, transaction costs, and informality," Journal of Development Economics, 86(2), 356-366. 
GiUliano, P., AND M. Ruiz-ARRANZ (2009): “Remittances, financial development, and growth," Journal of Development Economics, 90(1), 144-152.

Gupta, S., C. A. PAtTillo, And S. WAGH (2009): “Effect of Remittances on Poverty and Financial Development in Sub-Saharan Africa," World Development, 37(1), 104-115.

Halliday, T. (2006): "Migration, Risk, and Liquidity Constraints in El Salvador," Economic Development and Cultural Change, 54(4), 893-925.

HARRIS, J. R., AND D. F. TERRY (eds.) (2013): Remittance Flows to Post-Conflict States: Perspectives on Human Security and Development, Pardee Center Task Force Report. The Frederick S. Pardee Center for the Study of the Longer-Range Future, Boston University, Boston, Mass.

HARVEY, P., AND K. SAVAGE (2007): “Remittances during crises: Implications for humanitarian response," HPG briefing paper 26, Overseas Development Institute, London.

Hunter, L. M., S. Murray, and F. Riosmena (2013): “Rainfall Patterns and U.S. Migration from Rural Mexico," International Migration Review, 47(4), 874-909.

KAHN, M. E. (2005): “The Death Toll from Natural Disasters: The Role of Income, Geography, and Institutions," The Review of Economics and Statistics, 87(2), 271-284.

KEen, M., P. K. FReEMAN, AND M. MAni (2003): “Dealing with Increased Risk of Natural Disasters: Challenges and Options," IMF Working Papers 03/197, International Monetary Fund.

LAFRAMBOISE, N., AND B. LOKO (2012): “Natural Disasters: Mitigating Impact, Managing Risks," IMF Working Papers 12/245, International Monetary Fund.

Le De, L., J. C. GAillard, AND W. Friesen (2013): “Remittances and disaster: a review," International Journal of Disaster Risk Reduction, 4, 34 - 43.

(2015): "Poverty and Disasters: Do Remittances Reproduce Vulnerability?," The Journal of Development Studies, 51(5), 538-553.

LoAyzA, N. V., E. OlaberRíA, J. Rigolini, And L. ChristiAensen (2012): “Natural Disasters and Growth: Going Beyond the Averages," World Development, 40(7), 13171336.

Mohapatra, S., G. JosepH, AND D. RATHA (2012): “Remittances and natural disasters: ex-post response and contribution to ex-ante preparedness," Environment, Development and Sustainability, 14(3), 365-387.

MOOKERJEe, R., AND J. ROBERTS (2011): “Banking services, transaction costs and international remittance flows," Applied Economics Letters, 18(3), 199-205. 
MundACA, B. G. (2009): “Remittances, Financial Market Development, and Economic Growth: The Case of Latin America and the Caribbean," Review of Development Economics, 13(2), 288-303.

Naudé, W., And H. Bezuidenhout (2014): “Migrant Remittances Provide Resilience Against Disasters in Africa," Atlantic Economic Journal, 42(1), 79-90.

NoY, I. (2009): "The macroeconomic consequences of disasters," Journal of Development Economics, 88(2), 221-231.

Parry, M., O. Canziani, J. Palutikof, P. van der Linden, and C. Hanson (eds.) (2007): Climate Change 2007: Impacts, Adaptation and Vulnerability. Cambridge University Press, Contribution of Working Group II to the Fourth Assessment Report of the Intergovernmental Panel on Climate Change, 2007.

RADDATZ, C. (2007): "Are external shocks responsible for the instability of output in low-income countries?," Journal of Development Economics, 84(1), 155-187.

RASMUSSEN, T. N. (2004): "Macroeconomic Implications of Natural Disasters in the Caribbean," IMF Working Papers 04/224, International Monetary Fund.

Reuveny, R., And W. H. MoOre (2009): “Does Environmental Degradation Influence Migration? Emigration to Developed Countries in the Late 1980s and 1990s," Social Science Quarterly, 90(3), 461-479.

RoODMAN, D. (2009): "How to do xtabond2: An introduction to difference and system GMM in Stata," Stata Journal, 9(1), 86-136.

SiRKECI, I., J. H. COHEN, AND D. RATHA (eds.) (2012): Migration and remittances during the global financial crisis and beyond. The World Bank, Washington, D.C.

SKIDMORE, M., AND H. TOYA (2002): “Do Natural Disasters Promote Long-Run Growth?," Economic Inquiry, 40(4), 664-687.

Skoufias, E. (2003): "Economic Crises and Natural Disasters: Coping Strategies and Policy Implications," World Development, 31(7), 1087-1102.

STROBL, E. (2012): “The economic growth impact of natural disasters in developing countries: Evidence from hurricane strikes in the Central American and Caribbean regions," Journal of Development Economics, 97(1), 130-141.

TOYA, H., AND M. SKIDMORE (2007): “Economic development and the impacts of natural disasters," Economics Letters, 94(1), 20-25.

Weiss Fagen, P. (2004): “Remittances in crises. A Haiti case study," Hpg background paper, Overseas Development Institute, London. 
WORLD BANK (2013): Building Resilience. The World Bank, Washington DC.

WU, T. (2006): "The role of remittances in crisis: an Aceh research study," Hpg background paper, Overseas Development Institute, London.

YANG, D. (2008): “Coping with Disaster: The Impact of Hurricanes on International Financial Flows, 1970-2002," The B.E. Journal of Economic Analysis \& Policy, 8(1), 13.

YANG, D., AND H. CHOI (2007): “Are Remittances Insurance? Evidence from Rainfall Shocks in the Philippines," World Bank Economic Review, 21(2), 219-248. 
Additional Tables 


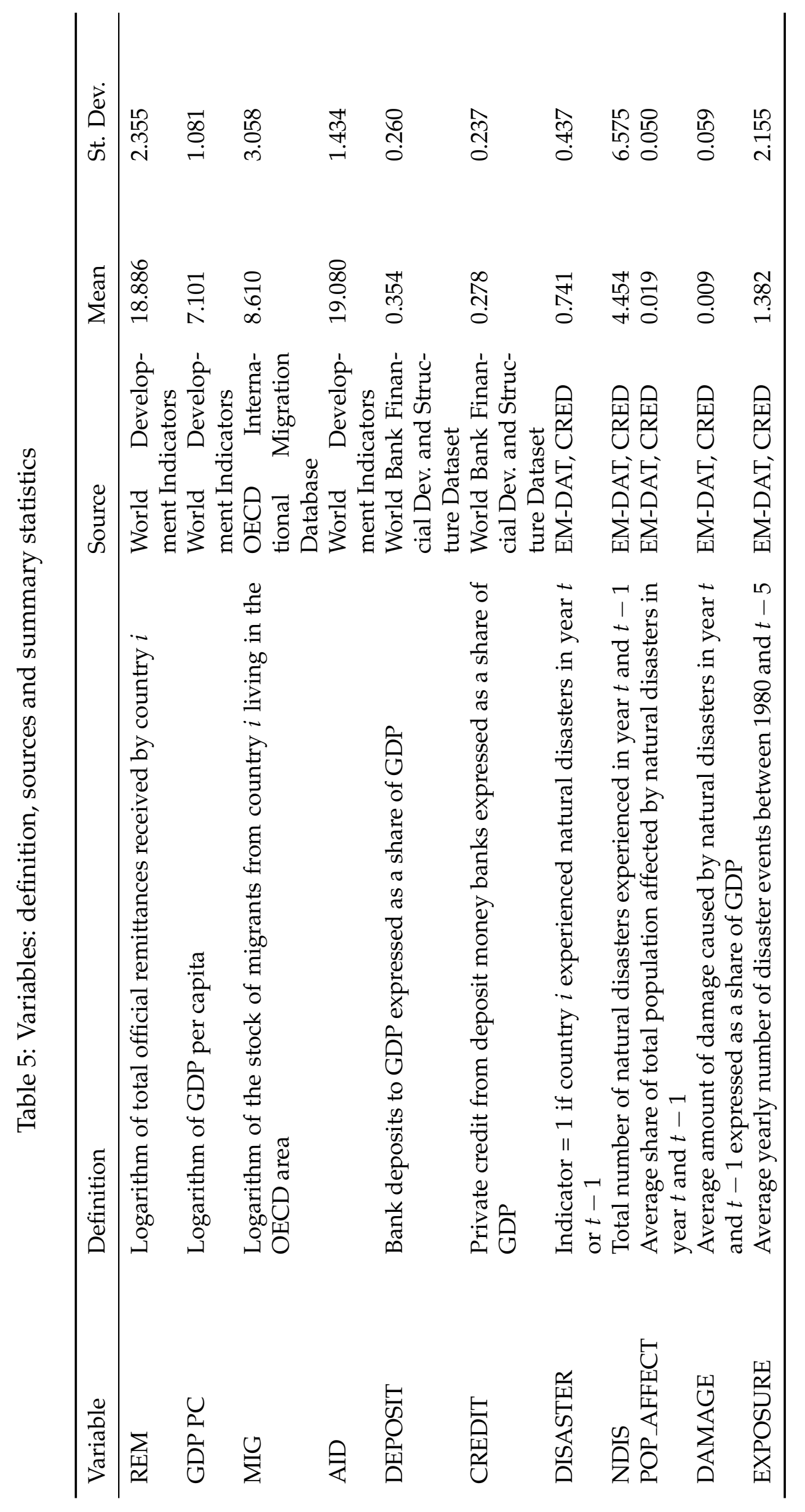


Table 6: Sample of countries

\begin{tabular}{lll}
\hline Albania & Guyana & Paraguay \\
Algeria & Haiti & Peru \\
Argentina & Honduras & Philippines \\
Armenia & India & Russia \\
Bangladesh & Indonesia & Rwanda \\
Belize & Iran & Saint Kitts and Nevis \\
Benin & Jamaica & Saint Lucia \\
Bolivia & Jordan & St. Vincent and the Grenadines \\
Botswana & Kazakhstan & Samoa \\
Brazil & Kenya & Senegal \\
Bulgaria & Kyrgyzstan & Seychelles \\
Burkina Faso & Laos & Sierra Leone \\
Burundi & Lesotho & Solomon Islands \\
Cambodia & Libya & South Africa \\
Cameroon & Lithuania & Sri Lanka \\
Cape Verde & Macedonia & Sudan \\
Chile & Madagascar & Suriname \\
Colombia & Malawi & Swaziland \\
Congo & Malaysia & Syria \\
Costa Rica & Mali & Tanzania \\
Dominica & Mauritania & Thailand \\
Dominican Republic & Mauritius & Togo \\
Ecuador & Mexico & Tonga \\
Egypt & Moldova & Tunisia \\
El Salvador & Mongolia & Turkey \\
Ethiopia & Morocco & Uganda \\
Fiji & Mozambique & Uruguay \\
Gabon & Nepal & Vanuatu \\
Georgia & Niger & Venezuela \\
Ghana & Nigeria & Vietnam \\
Grenada & Pakistan & Yemen \\
Guatemala & Panama & Zambia \\
Guinea-Bissau & Papua New Guinea & \\
\hline & & \\
\hline & & \\
\hline
\end{tabular}

